\title{
Survey
}

\section{Recent Developments in State Aid Law}

\author{
Jacques Derenne, Peter Citron, Mateo Domecq, \\ and Tom Mylrea-Lowndes*
}

\section{Introduction}

In the last eighteen months, there have been some interesting developments in State aid law both in terms of legislative changes and in terms of judgments being issued in important cases of the General Court (GC) and the Court of Justice of the European Union (CJEU). Given the constraints imposed by a survey of this nature, we cannot cover each of these developments in great detail. Therefore, from a legislative perspective, our analysis is limited to a brief overview of the reform of two Regulations which form part of the Commission's State aid modernisation programme.

The modernisation programme has three main objectives, closely linked: (i) to foster growth in a strengthened dynamic and competitive internal market; (ii) to focus enforcement on cases with the biggest impact on the internal market; (iii) to streamline rules and enable faster decisions. The European Commission wishes State aid control to more effectively target sustainable growth-enhancing policies while at the same time encouraging budgetary consolidation, limiting distortions of competition and keeping the single market open. Furthermore, although these aspects are not covered in the present article, it is worth keeping in mind that the Commission's modernisation proposals also include the revision, streamlining, and possibly the consolidation of State aid guidelines to make them consistent with the common principles for assessing the compatibility of aid with the internal market in the following fields:

- regional aid (new guidelines adopted in June 2013 and effective as from 2014);

- research \& development and innovation (consultation closed and issue papers under discussion with a view to proposing new guidelines);

- environmental and energy aid (draft new guidelines to be adopted in December 2013 or in early 2014);

- risk capital (draft new guidelines being discussed with the Member States and to be adopted soon);

* Jacques Derenne is a partner at Hogan Lovells, Brussels, and an associate professor at the University of Liège where he lectures State aid law in the LL.M on Competittion and IP Law; he also teaches State aid law at the

\section{Key Points}

- In the field of State aid, the Commission has launched a modernisation programme which includes, among many other elements, the adoption of amendments to the procedural regulation, and a revision of the scope of the general block exemption regulation.

- In various judgments, the European courts have shed new light on elements essential to the definition of State aid-namely the concept of undertaking, the notion of advantage, the private creditor test, as well as the circumstances in which State resources are included.

- broadband (new guidelines adopted in December 2012);

- aviation (consultation launched in July 2013; guidelines to be adopted in December 2003 or in early 2014); and

- rescue and restructuring aid (new draft guidelines adopted on 5 November 2013, under consultation).

In addition, as part of its modernisation programme, the Commission is also currently reviewing the General Block Exemption Regulation and the de minimis regulation (consultation on a second draft regulation in July 2013). It is also worth noting that the Commission will clarify and better explain the notion of State aid in a new 'State aid notice'. This will take the form of an interpretative communication, which will give a synthetic and pedagogical overview of the notion of State aid, as construed by the case law, but as the Commission understands it (as for other interpretative communications, the Commission is not allowed to add anything to existing law). The impact of this new notice, which is expected to be published in draft at the end of 2013 or early 2014, is, however, regarded as being very important in view of its

Brussels School of Competition. Peter Citron is counsel, Mateo Domecq is associate, and Tom Mylrea-Lowndes is trainee-solicitor, at Hogan Lovells, Brussels. 
effects on the Commission's own decision-making practice, on economic and social actors and the scope of their economic activity being caught by State aid law, and on national judges.

Lastly when it comes to the case law of the European Courts, our survey centres on a selection of cases, all of which relate to the notion of State aid. In the flow of decisions and court cases adopted during one year, it has been decided to focus, following a quite subjective selection and in view of the limited scope of the present survey, on cases ruled by the General Court (GC) and the CJEU, setting aside very interesting Commission decisions and national courts judgments.

\section{State aid modernisation}

In this section, we focus on two legislative developments that have taken place in the area of State aid law in the past twelve months. In particular, we seek to provide an overview of two important procedural amendments that were adopted in July 2013. The first legislative change was the adoption of a regulation amending Regulation No 659/1999 (the procedural regulation), and the second legislative amendment concerns the reform of Regulation No 994/98 (the enabling regulation). These two regulations were published on 31 July 2013 in the Official Journal of the European Union and entered into force on 20 August 2013.

\section{A. Reforming Regulation 659/1999}

On 22 July 2013, the Council of the European Union adopted a Regulation amending Regulation No 659/1999. It aims to make the complaints procedure more effective, gives wider investigative powers to the Commission and introduces a framework for formal cooperation between the Commission and national courts.

\section{Complaints}

The amended Procedural Regulation introduces some additional requirements for the submission of a complaint informing the Commission of any alleged unlawful aid or any alleged misuse of aid. The complaining party will now have to demonstrate a legitimate interest and complete a compulsory complaint form, which it is hoped will help improve the efficiency and transparency of the complaints procedure.

In certain circumstances, the Commission may decide not to respond to complaints (which could be seen as a legislative change to the current requirements under EU case law). ${ }^{1}$ Prior to the adoption of the amending regula- tion, the Commission was bound to diligently and impartially examine any complaint it received. Now, the Commission may decide not to respond to a complaint where the complaint does not comply with the compulsory complaint format or where the substance of the complaint does not sufficiently 'show, on the basis of a prima facie examination, the existence of unlawful aid or misuse of aid'. The complainant must nonetheless be informed of the Commission's decision not to respond and be given a prescribed period in which to submit further comments. If the complainant does not submit further comments within this time, the complaint is deemed to have been withdrawn.

It is true that the Commission has limited resources. It is also true that, each year, hundreds of complaints (apparently 30 per cent) are completely unfounded or 'frivolous'. Nevertheless, one cannot help (and this is not new) but feel that complainants are not always treated as fairly as they should be in competition law (which would, at least, require a 'prima facie right of review'). If not duly handled by the Commission, the only option left to complainants is to bring the matter before the courts, in limited circumstances (ie not where the complaint is clearly unfounded), and argue that a Council Regulation may not ignore the application of certain general principles of European law.

\section{Request for information from third parties}

The Procedural Regulation fails to provide specific rights protecting the interests of third parties vis-à-vis the relevant Member State. The formal procedure remains limited (as provided by the Treaty) to a bilateral discussion between the Member State and the Commission.

However, the Commission has now been given the power to require interested third parties (being any Member State other than the notifying or interested Member State and any concerned market player, such as an undertaking or an association of undertakings) to provide 'all market information necessary for completing its assessment, if the information provided by the Member State concerned during the course of the preliminary investigation is not sufficient, taking due account of the principle of proportionality, in particular for small and mediumsized enterprises'.

In addition, the Commission has also been given the power to impose fines and penalties when undertakings or associations of undertakings 'intentionally or through gross negligence' supply 'incorrect or misleading information' in response to a request for information from the 
Commission or supply 'incorrect, incomplete or misleading information' in response to a decision of the Commission. Where these conditions are met, the Commission may, when it deems it to be necessary and proportionate, impose fines of up to 1 per cent of total turnover in the preceding financial year (it is worth noting that this new power to impose fines and penalties has created a third area of unlimited jurisdiction for the GC and the CJEUafter Regulation No 1/2003 and the Computer Reservation Systems Regulation).

In some ways, these new sanctions align the rules of procedure for State aid with the relevant legislation relating to anticompetitive practices. This is only true, however, with regard to the treatment of undertakings and associations of undertakings, being interested third parties in a procedure, which is only between the relevant Member State and the Commission. It must also be pointed out that a Member State which does not provide the information requested within the prescribed time limit, or which provides incomplete information, will receive only 'a reminder' from the Commission. This preferential treatment makes State aid decidedly different from other areas of competition law.

The Commission's new powers are tightly controlled (again in order to protect the interests of the relevant Member States): the Commission may only request information once they have opened a formal investigation procedure, which they have identified as being ineffective, relating to the beneficiaries of the aid in question. The Commission must also obtain the prior agreement of the Member State concerned (which may considerably limit the effective powers of the Commission: in other words, the main source of the inefficiency of the procedure-by lack of response or accurate responses, quite often deliberately - will have to agree on the decision to exercise powers ensuring the efficacy of the investigation!). However, an undertakings' legitimate interest to protect their business secrets and other confidential information is protected as is the right to anonymity (in relation to the Member State concerned) of a non-beneficiary undertaking.

The Commission may now open investigations by economic sector or aid instrument.

Member States will probably attempt to use all of their influence to prevent the introduction of the amended Procedural Regulation from resulting in the implementation of more effective State aid proceedings against them.

\section{Cooperation between the Commission and the national courts}

A new chapter, entitled 'cooperation with national courts' has been added to the Procedural Regulation. National courts will now have the power to make a formal request (as opposed to an informal communication with the
Commission, which has not tended to be very successful) asking the Commission to 'transmit to them information in its possession or its opinion on questions concerning the application of State aid rules'. In return, the Commission may, acting of its own accord, submit written observations to the courts of the Member States, where the coherent application of Article 107(1) or Article 108(3) of the TFEU so requires. The Commission may also ask the relevant court of the Member State to provide them with documents at their disposal, where such documents are required for the Commission's assessment of the matter. However, the Commission will only be able to intervene in a case being heard before a national court when they have been authorised to do so by that national court.

The formal introduction of these new rules has created a set of principles of cooperation analogous to the principles of anticompetitive practices defined in Article 15 of Regulation No 1/2003. They should permit the Commission to play a more prominent and effective role in ensuring that the rules on State aid are properly applied by national courts. Parties coming before these courts will have a vital role to play in notifying the Commission of any cases that justify its intervention.

This may be, when also taking into account the Commission's new investigation powers, the most significant change to the rules of procedure for State aid in nearly fifty years (since Costa $v$ ENEL).

\section{B. Reforming Regulation (EC) No 994/98}

As part of the Commission's State Aid Modernisation Initiative, the Council of the European Union has amended Regulation (EC) No 994/98 in order to introduce new categories of aid for which block exemptions may be made.

To this end, the Council has included a number of new categories of aid in the Enabling Regulation for which the Commission may adopt Regulations, including: research and development, culture, natural disasters, sport, certain aspects of agriculture, forestry, and fishing.

As the Commission's decision-making practice has shown, these categories of aid will often have a limited effect on the exchanges between Member States and result in only insignificant distortions of competition. This, in itself, justifies the introduction of a block exemption.

The consultation on the draft amendment to the General Block Exemption Regulation, which applies this new Enabling Regulation, was completed in September 2013.

\section{European Court cases, 2012-2013}

This section provides a selective, and brief, overview of some of the State aid cases on which the European 
Courts have ruled since the end of 2012 (until early November 2013, at the time of writing the present article). As will become apparent, a large number of the judgments covered here focus on the application of the conditions of Article 107(1) TFEU (notion of aid). In this respect, the judgments cover the following issues:

- the concept of an undertaking;

- the concept of advantage;

- the private creditor test;

- the concept of State resources; and

- the conditions of affectation of inter-State trade and distortion of competition.

The Courts in these judgments, however, do not introduce any significant changes but rather they limit themselves to reiterating prior case law and applying it to particular facts of each case, although thereby creating certain nuances and new areas of legal development. It is true that EU case law mainly responds to the endless creativity of the Member States in State aid matters, which tends to expose the notion of State aid to various levels of strain (sometimes leading to a restriction of the notion and sometimes leading to an extension of the notion).

\section{A. 'Undertakings' for the purposes of Article 107(1) TFEU}

\section{Mitteldeutsche Flughafen and Flughafen Leipzig Halle $v$ Commission}

On 19 December 2012, the CJEU handed down its judgment in the appeals by Mitteldeutsche Flughafen (MF) and Flughafen Leipzig-Halle (FLH) against a General Court judgment relating to a European Commission decision that a grant of $€ 350$ million by Germany to FLH in the form of capital contributions for the purpose of funding investments in the construction of a new southern runway constituted compatible State aid. ${ }^{2}$ The General Court held that the construction of airport infrastructure is part of the economic activity of operating an airport and that public funding of infrastructure which is necessary for the operation of the airport alleviates the costs that the airport operator would normally have to bear and, therefore, constitutes State aid. The parties argued that the General Court had infringed Article 107(1) of the TFEU and the principles of nonretroactivity, legitimate expectations, and legal certainty, but the CJEU dismissed the appeal in its entirety.

\footnotetext{
2 CJEU: Case C-288/11 P, Mitteldeutsche Flughafen AG and Flughafen LeipzigHalle GmbH v Commission, not yet reported.
}

3 Ibid., paras $23-34$.
The central argument of the parties had been that the construction or extension of airport infrastructure did not constitute an economic activity governed by EU State aid law, so that the financing of it could not be held to constitute State aid. They relied heavily on a 1994 Commission Communication which stated that 'the construction or enlargement of infrastructure projects (such as airports, motorways, bridges, etc.) represents a general measure of economic policy which cannot be controlled by the Commission under the Treaty rules on State aid. ${ }^{3}$

The CJEU noted that the General Court had considered the Commission's appreciation of the Aéroports de Paris case (Case T-238/98), which recognised that, as of 2000, an airport operator is in principle to be regarded as engaging in an economic activity within the meaning of Article 107(1) of the TFEU. For the purposes of establishing whether the construction of the new southern railway could be characterised as an economic activity, the General Court had made an assessment of that activity and examined its nature in accordance with the case law. In doing so, the General Court found that the construction of the runway could not be dissociated from the operation by FLH of airport infrastructure, which constitutes an economic activity. ${ }^{4}$

The CJEU confirmed the Commission's broad interpretation of the notion of State aid within the meaning of Article 107(1) TFEU. An economic activity is present if an enterprise engages in economic activity-offering goods or services in a market-for commercial purposes. At point 50, it noted that: 'It is settled case law that, first, in the field of competition law the concept of undertaking covers any entity engaged in an economic activity, regardless of the legal status and the way in which it is financed and, secondly, any activity consisting in offering goods or services on a given market is an economic activity. It follows from this that whether or not an activity is economic in nature does not depend on the private or public status of the entity engaged in it or the profitability of that activity. ${ }^{5}$

Although this judgment concerns the airport sector, it is likely that the principles established in it will apply to the public financing of other kinds of infrastructure in the future, and that a large part of public financing of infrastructure will be regarded as State aid. As a consequence, we can expect numerous State aid notifications concerning public infrastructure projects in the future. This judgment largely reinforces the Commission's position vis-à-vis the Member States with respect to these infrastructure projects.

\footnotetext{
4 Ibid., para. 44

5 Ibid., para. 50
} 


\section{Germany v Commission: nature conservation organisations}

In this case, the measures at issue involved the gratuitous transferal of federally-owned natural heritage sites to the Lander and the Deutsche Bundesstiffung Umwelt (German Environment Foundation), and the funding of large-scale nature conservation projects. ${ }^{6}$ Furthermore, the Lander could in turn also transfer these areas gratuitously to nature conservation organisations. The recipients of these natural heritage sites would bear the burden of having to ensure that they are able to preserve these sites. Moreover and subject to certain restrictions, the German scheme allowed the conservation entities to draw revenues from the land they managed through activities such as hunting leases, fishing leases, sales of wood obtained from forestry upkeep activities and tourism. The revenues generated would be offset against the costs of the nature conservation projects and if there were excess in revenues, these would be repaid to the institution which awarded the grant to the conservation entity in the first place.

The key issue that the General Court had to rule on was to determine whether the conservation entities constituted 'undertakings' for the purposes of Article 107(1) TFEU or put simply whether they performed 'economic activities' which consisted in offering goods or services in a given market. Given the public policy objective that these entities pursue, the debate was focused on whether the ability to perform revenue-generating activities was sufficient for them to be considered as undertakings.

The Court found that even though these secondary activities resulted from these entities' primary activity of protecting the environment, they were not rendered obligatory by the latter. Thus, by offering these goods or services in markets open to competition, these nature conservation entities are pursuing an objective that can be dissociated from the social policy objective of protecting the environment. ${ }^{7}$ Therefore, in line with prior case law, the General Court found that these entities did constitute undertakings for the purposes of competition law. ${ }^{8}$ Lastly, since the secondary activities involved participation in the market that was capable of undermining the objectives of competition law, the General Court explained that it was irrelevant that the revenues generated had to be employed to finance the conservation tasks. ${ }^{9}$

\footnotetext{
6 GC: Case T-347/09 Germany v Commission, not yet reported.

Ibid., para. 41.

Ibid., para. 43

Ibid., para. 50
}

\section{B. The advantage}

\section{France $v$ Commission: implied unlimited State guarantee}

On 20 September 2012, the General Court issued a judgment confirming the Commission's decision finding that France had granted aid to La Poste. The Commission had found that France had granted incompatible State aid to La Poste in the form of an implied unlimited State guarantee. ${ }^{10}$ Given its legal status, La Poste was not subject to the ordinary law rules on administration and winding up and, as a result, the Commission had found that creditors of La Poste were in a more favourable situation than private creditors. Contrary to what occurred under the application of ordinary law rules governing compulsory administration or winding-up, the creditor of a publicly owned establishment such as La Poste did not run the risk of seeing his claim cancelled because of a judicial winding-up procedure being triggered.

The General Court endorsed the Commission's position and in line with previous case law, found that an unlimited State guarantee allows the recipient of such a guarantee to benefit from credit terms that are more favourable than the terms it would have obtained on its merits alone and therefore eases the pressure on its budget. Therefore, unsurprisingly, the implied unlimited State guarantee from which La Poste had benefitted granted it an advantage over its competitors. ${ }^{11}$

\section{Poste Italiane SpA v Commission}

On 13 September 2013, the General Court handed down its judgment on an action for annulment by Poste Italiane SpA against a decision of the European Commission which found that aid (in the form of high interest rates) paid to Poste Italiane was incompatible and should be recovered. ${ }^{12}$ The Commission had found that Poste Italiane's banking activities had received an economic advantage. Under an Italian Treasury scheme (dating from 1945), Poste Italiane was legally required to deposit funds collected from its current accounts with the Treasury. The Treasury paid interest on those deposits by virtue of a methodology established under Italian budgetary law (under a convention dated 2006), which the Commission considered to be at a higher rate than a private borrower would have been prepared to pay.

The General Court held that the Commission should not have relied solely on a comparison between the

10 GC: Case T-154/10 France $v$ Commission, not yet reported.

11 Ibid., paras 106-108.

12 GC: Case T-525/08 Poste Italiane SpA v Commission, not yet reported. 
Treasury rates and the private borrower rates but should have looked at the overall effect of the State intervention, particularly the fact that Poste Italiane was legally obliged to place the funds with the Treasury.

The General Court also found that the Commission had erred in its assessment of the alternative investment strategies that would have been available to Poste Italiane in the absence of that legal obligation. In one case the Commission had erroneously deducted management fees. The Commission had also used too short a period (three years) to assess the profitability of the alternative investment management strategy, and wrongly concluded that capital gains or capital losses could not be considered in an ex ante analysis of the total returns available.

In light of the above, the CJEU held that the Commission had not established to the requisite legal standard that Poste Italiane received an economic advantage such that the measure constituted State aid. The General Court, therefore, annulled the Commission's decision. This case shows the importance of the overall approach in examining State measures under State aid law.

\section{The private investor principle}

\section{Commission v Buczek Automotive}

On 21 March 2013, the CJEU rejected an appeal by the European Commission against a General Court judgment that annulled a Commission decision requiring recovery of State aid granted to the Polish steel producer Technologie Buczek Group. ${ }^{13}$ The CJEU concluded that the General Court had not made any error of law in finding that the Commission had not provided sufficient reasons or analysis to support its conclusion that the Polish authorities had not acted like a private creditor in the way in which it sought to recover public debts from the company. The Polish authorities in this case had chosen not to start bankruptcy proceedings against the group, but had chosen instead legal proceedings for the recovery of debt.

The CJEU considered that the Commission could not have concluded that the potential recovery under a restructuring would not have exceeded that obtained by liquidation of the company without a comparison of the duration of bankruptcy proceedings against the legal procedure for the recovery of debts. ${ }^{14}$

\section{Frucona Kosice $v$ Commission}

On 24 January 2013, the CJEU set aside the General Court's judgment upholding a Commission decision

\footnotetext{
13 CJEU: Case C-405/11 P Commission v Buczek Automotive, not yet reported. 14 Ibid., paras 54-64.

15 CJEU: Case C-73/11 P Frucona Kosice v Commission, not yet reported.

16 Ibid., para. 78.
}

finding that the Slovakian tax office had granted incompatible State aid to Frucona (a producer of spirit and spirit-based beverages in Slovakia) in the form a write-off of a tax debt. ${ }^{15}$

Under Slovak Law No 328/1991, there are two procedures, which are supervised by the courts for companies that find themselves in a position of indebtedness. Whilst the bankruptcy procedure has the result that the indebted company ceases to the exist, under the arrangement procedure, the indebted company is allowed to pursue its activities, leading to an agreement under which the indebted company repays a portion of its debt in return for the balance being written off. In this case, Frucona, who had benefitted in the past from several deferrals for the payment of its tax debt, opted for the arrangement procedure with the acceptance of all of its creditors including the local tax office. The arrangement involved paying each creditor 35 per cent of the amount owed to each of them.

The central issue that the CJEU faced in this instance was to determine whether the General Court had failed to correctly apply the private creditor test by not establishing whether the Commission had actually taken into account the duration of the bankruptcy procedure in its assessment of the test. After briefly recalling the basic principles developed by case law on the private creditor test, the CJEU stated that all information that is liable to have a significant influence on the decision-making process of a normally prudent and diligent private creditor, in a situation as close as possible to that of the public creditor seeking to recover sums due to it by a debtor experiencing difficulty in making the payments, must be regarded as relevant. ${ }^{16}$ Lastly, the Court considered that the duration of the procedure was a factor that could have a significant influence and that the General Court had failed to establish whether the Commission had taken into account the duration of the bankruptcy procedure in its assessment of the private creditor test. ${ }^{17}$

\section{Nitrogenmuvek Vegyipari v Commission}

On 27 February 2013, the General Court issued a ruling dismissing an action of annulment brought against a Commission decision finding that the grant of two loans by the Hungarian development bank, which had been guaranteed by the Hungarian State, constituted unlawful and partially incompatible aid, which had to be recovered. ${ }^{18}$

The General Court found that the Commission had correctly applied the private investor principle since it had checked whether the beneficiary of the loans would

\footnotetext{
17 Ibid., paras $81-88$.

18 GC: Case T-387/11 Nitrogenmuvek Vegyipari $v$ Commission, not yet reported.
} 
have been able to secure the same loans on the capital market. ${ }^{19}$ Moreover, it is also worth noting that the General Court found that the fact that the collateral had a value which was over 70 per cent of the loans did not imply that the beneficiary would have obtained loans at comparable rates to those granted by the Hungarian Development Bank. $^{20}$

In addition, it is also worth underlining the General Court's rejection of the applicant's argument that the Commission had committed a manifest error in rejecting the ' $\mathrm{BB}$ ' rating that had been attributed to the beneficiary by the Hungarian Development bank and replacing it by its own 'CCC' rating. The General Court pointed out that in line with the reference rate communication, the Commission does not have to accept a rating attributed by the national bank. This is even more relevant when the State authorities refuse to provide the necessary information that would enable the Commission to check the attributed rating. ${ }^{21}$

\section{State resources}

\section{French Fruit and Vegetables}

On 27 September 2012, the General Court dismissed three challenges of a Commission decision that found that French 'contingency plans' for the fruit and vegetable sector constituted unlawful and incompatible State aid. ${ }^{22}$ The General Court found that the Commission had been correct to find that the measures at issue constituted State aid even though they were co-financed by voluntary contributions from farmers' associations. The relevant criterion for determining whether an aid measure is funded through State resources is not the initial origin of the resources but the degree of intervention by the public authority in the definition of the measure and its method of financing. ${ }^{23}$

The General Court found that the use of State resources derived from the following elements:

- Oniflhor, a public institution under the supervision of the French State, decided unilaterally on the sums allocated and the amount of contributions;

- the measures were determined by Oniflhor's decisions;

- the Ministry of Agriculture had a far reaching and regular power of audit;

- the State played a predominant role in the farmers' associations (in particular, with respect to the amendment of rules and designation of representatives).

\footnotetext{
19 Ibid., para. 16-23.

20 Ibid., paras $35-38$.

21 Ibid., paras $40-43$.

22 GC: Case T- 139/09 France $v$ Commission, not yet reported.

23 Ibid., para. 63.
}

\section{Bouygues and Bouygues Telecom v Commission (France Telecom case)}

On 19 March 2013, following cross appeals by Bouygues and the Commission, the CJEU set aside the judgment of the General Court annulling a Commission decision finding that France had granted France Telecom unlawful and incompatible State aid via the combination of public statements of support by the Minister for economic affairs and the offer of a shareholder loan, which was not taken up by France Telecom. ${ }^{24}$

The CJEU held that the General Court erred in law, both in its review of the Commission's identification of the State intervention measure conferring State aid and in the examination of the links between the advantage identified and the commitment of State resources found by the Commission. The General Court wrongly required a close connection between the advantage and the commitment of State resources. When determining the existence of State aid, the Commission must establish a sufficiently direct link between the advantage given to the beneficiary and a reduction of the State budget or a sufficiently concrete economic risk of burdens on that budget. ${ }^{25}$ However, contrary to what the General Court found, it is not necessary that such a reduction, or even such a risk, should correspond or be equivalent to that advantage, or that the advantage should have as its counterpoint such a reduction or such a risk, or be of the same nature as the commitment of State resources from which it derives. ${ }^{26}$

The CJEU went on to give final judgment on the issues that were considered by the General Court, ruling that the Commission had rightly found that, in this case, an advantage was granted through State resources within the meaning of Article 107(1) of the TFEU. Whilst it was true that France Telecom did not sign the loan agreement sent to it, the company could have signed it at any time and acquired the right to obtain immediate payment of $€ 9$ billion. The CJEU considered that the mere potential of the arrangements was enough. ${ }^{27}$

The CJEU referred the actions for annulment back to the General Court for judgment on the pleas raised before it by France and France Telecom on which it did not give a ruling. ${ }^{28}$

This judgment provides important clarification of when a public statement of support can qualify as State aid.

\footnotetext{
24 CJEU: Joined Cases C-399/10 P and C-401/10 P Bouygues and Bouygues Telecom $v$ Commission, not yet reported.

25 Ibid., para. 109.

26 Ibid., para. 110.

27 Ibid., paras $137-139$.

28 Ibid., para. 142 .
} 


\section{Doux Elevage SNC et Coopérative agricole UKL-ARREE $\checkmark$ Ministère de l'Agriculture et CIDEF}

In this case, ${ }^{29}$ the competent national court raised a question for a preliminary ruling concerning the interpretation of Article 107(1) TFEU. More specifically, the question which needed answering in this instance was whether a decision by which a national authority extends to all traders in an agricultural industry an inter-trade agreement which introduces the levying of a compulsory contribution, for the purposes of financing common activities decided by the organisation, constitutes State aid.

In line with previous case law, the Court found that there was no direct or indirect transfer of State resources because: (i) the sums provided by the payment of these contributions did not go through the State budget or through another public body; and (ii) the State relinquished any resources, in whatever form, which under national legislation, should have been paid into the State budget. The contributions, thus, remain private in nature throughout their lifecycle and, in order to collect those contributions in the event of nonpayment, the inter-trade organisation must follow the normal civil or commercial judicial process, having no State prerogatives. ${ }^{30}$

Furthermore, the Court pointed out that national authorities cannot actually use the resources resulting from the contributions to support certain undertakings, since it is the inter-trade organisation that decides how to use those resources, which are entirely dedicated to pursuing objectives determined by the organisation. Thus, these resources are not constantly under public control and are not available to State authorities. ${ }^{31}$

Lastly, the Court explained that the fact that the intertrade organisations are partly financed by the State and the fact that there is no separation in the accounts between private and public funds did not alter the conclusion that the element of 'State resources' has not been satisfied. Thus, private funds do not become State resources simply because they are used alongside sums which may originate from the State. ${ }^{32}$

\section{Aiscat v European Commission}

In Aiscat $v$ European Commission, the General Court upheld the Commission's decision dismissing the complaint made by the Italian association of concessionaires for the construction and operation of highways and road tunnels, Aiscat. ${ }^{33}$

29 CJEU: Case C-677/11 Doux Elevage SNC et Coopérative agricole UKLARREE $v$ Ministère de l'Agriculture et CIDEF, not yet reported.

30 Ibid., para. 32.

31 Ibid., para. 36

32 Ibid., paras $42-44$.
Aiscat had complained that the Italian authorities had granted State aid to the concessionaire CAV SpA which was owned by the Region of Veneto and la Azienda nazionale autonoma delle strade SpA(ANAS) which forms part of the Italian State. CAV SpA had been awarded the contract for the management and upkeep of a fragment of highway called La Passante. The competent public body adopted an administrative resolution which increased the toll to be paid for the use of a highway called La Tagenziale that was in direct competition with La Passante. This increase was then incorporated in the concession contracts signed between the concessionaires and ANAS. In particular, in the contract signed between ANAS and CAV SpA, CAV SpA undertook to reimburse ANAS for having financed the construction of $\mathrm{La}$ Passante. In exchange, CAV SpA would obtain among other sources of revenue: the product of the toll increase to be applied in the Tagenziale. The increase ensured that the toll would be the same for both highways despite the fact that La Passante covered a longer distance and according to Aiscat, since the product of the increase was used to finance the construction of La Passante, CAV had benefited from State aid.

Again, in line with previous case law, the General Court found that there was no transfer of State resources in this instance since no public body acquired any form of control or possession over the sums of money. The sums which were a product of the toll increase were paid directly to CAV, either through the concessionaires that manage the toll stations or via telepass. In other words, the transfer of resources took place between private undertakings, with no public body ever acquiring any form of control over the sums. ${ }^{34}$

\section{E. Effect on inter-state trade and distortion of competition}

\section{Italy $v$ Commission (Wam)}

When it comes to the conditions of affecting inter-state trade and distorting competition, the only judgment worth reporting on is the General Court's judgment in Italy $v$ Commission. ${ }^{35}$

In this case, the controversial measures involved two loans that had been granted by Italy to Wam Industriale Spa (a company active in the production and distribution of industrial mixers) for the purposes of penetrating markets in third countries. These measures had already

33 GC: Case T-182/10 Aiscat $v$ Commission, not yet reported.

34 Ibid., paras 103-106.

35 GC: Case T-257/10 Italy $v$ Commission, not yet reported. 
been scrutinised by the European Commission in 2004 which adopted a decision finding that Italy had granted unlawful and incompatible aid, and ordering the Italian State to recover the aid declared incompatible with the internal market. The decision was challenged and subsequently overturned by the General Court due to the Commission's failure to sufficiently motivate the application of the conditions of Article 107(1) TFEU to the measures in question. After the General Court's judgment ${ }^{36}$ was confirmed by the CJEU, ${ }^{37}$ the Commission adopted a new decision declaring that the Italian State had granted unlawful and incompatible aid and ordering the recovery of that part of the aid that was incompatible.

In the present judgment, the General Court, after carefully analysing the Commission's reasons as to why the loans in question were liable to affect inter-state trade and to distort competition within the Union, concluded that the Commission had not failed to comply with its duty to state reasons.

The General Court recalled the case law according to which, when State aid reinforces an undertaking compared with other undertakings competing in intra-EU trade, the latter must be regarded as influenced by that aid. Furthermore, regarding the condition of the distortion of competition, the General Court recalled that aid that is intended to release an undertaking from costs which it would normally have to bear in its day-to-day management or normal activities, in principle, distorts the conditions of competition. ${ }^{38}$ In this respect, the Court observed how the Commission had shown in its reasoning that the beneficiary was present both in European and international markets, that it held a significant part of those markets, and that it was in actual or potential competition with other undertakings in those markets. Thus, as a result of the loans, Wam had seen its position reinforced vis-à-vis other actual or potential competitors of other Member States. ${ }^{39}$

In addition, the conditions of competition would be altered because, unlike its actual or potential competitors, Wam did not need to finance its own programme to penetrate markets in third countries. Moreover, the loans permitted Wam to economise its resources and as a result would allow Wam to either increase its profits or sell its products at an inferior price in these third countries. Furthermore, the profits that are generated by these exporting activities could then be used by Wam to invest in the Union. ${ }^{40}$

In line with previous case law, the General Court explained that, contrary to Italy's assertions, in order to show that the two conditions are met, the Commission is not required to define the market in question and analyse its structure as well as the competitive relationships that arise. Lastly, the Court recalls that it is settled case law that since these two conditions are linked, the Commission is not required to analyse them separately provided that the Commission's reasoning clearly shows how these conditions have been fulfilled. ${ }^{41}$

doi:10.1093/jeclap/lpt072
36 GC: Joined Cases T-304/04 and T-316/04 Italy \& Wam SpA $v$ Commission ECR [2006] II-00064.

37 CJEU: Case C-494/06 P Commission v Italy and Wam SpA ECR [2009] I-03639.

38 See note 35 , paras $78-79$.
39 Ibid., para. 83.

40 Ibid., para. 84.

41 Ibid., para. 100 